\title{
Crude oil prices, macroeconomic indicators and the financial sector in Jordan: Dynamic causes and responses
}

\author{
Nawaf Abuoliem \\ Faculty of Business, Economics and Social Development, University of \\ Malaysia Terengganu, Kuala Nerus, Terengganu, Malaysia \\ nawafabuoliem@gmail.com

\section{Safwan Mohd Nor} \\ Faculty of Business, Economics and Social Development, University of \\ Malaysia Terengganu, 21030 Kuala Nerus, Terengganu, Malaysia; \\ Victoria Institute of Strategic Economic Studies, Victoria University, \\ Melbourne, Victoria 3000, Australia \\ safwan@umt.edu.my;safwan.mobdnor@live.vu.edu.au
}

\section{Ali Matar}

Department of Finance and Banking,

Jadara University, Irbid 21110, Jordan

amatar@jadara.edu.jo

\author{
Terrence Hallahan \\ College of Business, Victoria University, \\ Melbourne, Victoria 3000, Australia \\ terrence.ballahan@vu.edu.au
}

\begin{abstract}
This study contributes to the literature on the relationship between fundamental economic factors and stock price movements. We evaluate the relationship between domestic and international macroeconomic indicators and financial sector index in a frontier market that is Amman Stock Exchange (ASE) in Jordan. We employed the ARDL bound testing approach and the VECM Granger causality test to examine long and short run relationships and the direction of causality among the variables. Monthly time series data from January 2007 to December 2016 were used to identify the relationships for interest rate (positive), inflation rate (insignificant), money supply (insignificant), industrial production index (insignificant), producer price index (negative), trade balance (insignificant), and crude oil price (negative). Our findings indicate that the deposit interest rate positively influenced the financial sector in the short run and the long run, while the producer price index and global oil price had significant negative impacts on the financial sector. This study contributes actionable insight for policy makers and investors regarding how global and domestic factors have significant impact on the financial index in Jordan. The current study provides several important implications and recommendations for investors, policy makers and the government. For example, the results imply that global oil prices have a
\end{abstract}

\footnotetext{
Received: January, 2019 1st Revision: August, 2019

Accepted: September, 2019

DOI: $10.14254 / 2071$ 8330.2019/12-3/11
} 
significant impact on the financial index in Jordan, which indicates that the ASE is correlated with the global markets and is sensitive to shocks of the global indicators.

Keywords: financial market, econometrics, ARDL, VECM, causality, Jordan.

JEL Classification: E44, G12

\section{INTRODUCTION}

The relationship between fundamental economic factors and stock price movements has long been the subject of investigation in economics and finance literature, yet, it is not a settled area. Early research by Friedman and Schwartz (1963) found that changes in money supply could have a significant impact on stock prices. Studies by Fama and Schwert (1977), Fama (1981), and Geske and Roll (1983) document negative relations between stock returns and both expected and unexpected components of inflation rate. However, Roll (1988) found that only around a third of variation in stock prices could be explained by fundamental economic factors, a finding supported by Cutler, Poterba and Summers (1989) who evaluated the extent to which major movements in stock market indices could be explained by the arrival of news as fundamental economic shocks. Later studies by Fama and French (1988, 1989), Fama (1990) and Schwert (1990) found that three proxies for business conditions, the dividend yield, the default spread and the term spread, could better explain significant variation in stock prices. The majority of the research in the 1990's and 2000's continued to focus on the relationship between economic factors and stock price movements in developed markets. In the mid 2000's researchers turned their attention to emerging markets and the current decade has seen the scope of studies extended to frontier markets.

Global crude oil price fluctuations play a critical role in many economies around the world and have important implications for stock markets (Mensi, 2017), particularly emerging and frontier ones. In addition, crude oil prices are considered to be a major indicator for an economy and the stock markets of a country (Noor \& Dutta, 2017). However, the impact of oil prices differs from oil-importing countries to oilexporting countries. For exporting countries, increase in oil price has a positive influence on the trade balance, which will lead to surpluses, which will then increase the profits of domestic firms, and finally increase the demand on these firms' stocks (Adaramola, 2012). Moreover, macroeconomic indicators and stock prices have a strong correlation, as stock prices are significantly influenced by macroeconomic indicators (Borjigin et al., 2018). Against this background, the current study contributes to the research on the relationship between economic influences and stock prices in a frontier market by using both domestic and global macroeconomic indicators to explain the relationship between these indicators and the most important sector at the Amman Stock Exchange (ASE).

This study focused on Jordan's financial sector, which includes the banks and real estate sectors as well as the financial services sector. The study differed from previous studies because we focused on the period (January 2007 - December 2016) that is after the new distribution of ASE in June 2006. Second, this study covered the periods of the financial and political crises, such as the global financial crises of 2008, Arab spring crises of 2010 and the wars in Iraq and Syria in 2013. These events resulted in about two million refugees moving into a small country like Jordan. These refugee movements caused an imbalance in the macroeconomic indicators such as foreign trade and inflation. Moreover, crises such as the global financial crisis 2008-2009 have increased the risk aversion, fear and pressure in the stock markets around the globe thereby affected investors' expectations (Shahzad et al., 2017).

The ASE is considered to be one of the most effective markets in the Middle East. The S\&P country classification has classified it as a frontier market and ranked it among the top 10 emerging markets in the Middle East (Bekhet \& Matar, 2013). In particular, the financial sector plays an important role in influencing 
the national economy through the banks, which are considered the main financier of the economy (Drigă \& Dura, 2014).

Figure 1 shows the financial index (FI) during the study period. The chart reveals that FI was significantly influenced, especially in 2008 and 2014. At end of July 2008, the index reached its maximum level of 5,574 points. The index showed a significant decline during the four months that followed. At the end of November 2008, the FI had reduced to 3,735. In fact, data in the figure show that there is a decline during the periods between 2010-11 and 2011-13. During the period of January 2010 to December 2011, the index lost 568 points due to the decrease from 3,012 points to 2,444 points. Therefore, the significant decline in the index highlights that the extent of the impact on this index and the importance of studying the variables that can influence this index.

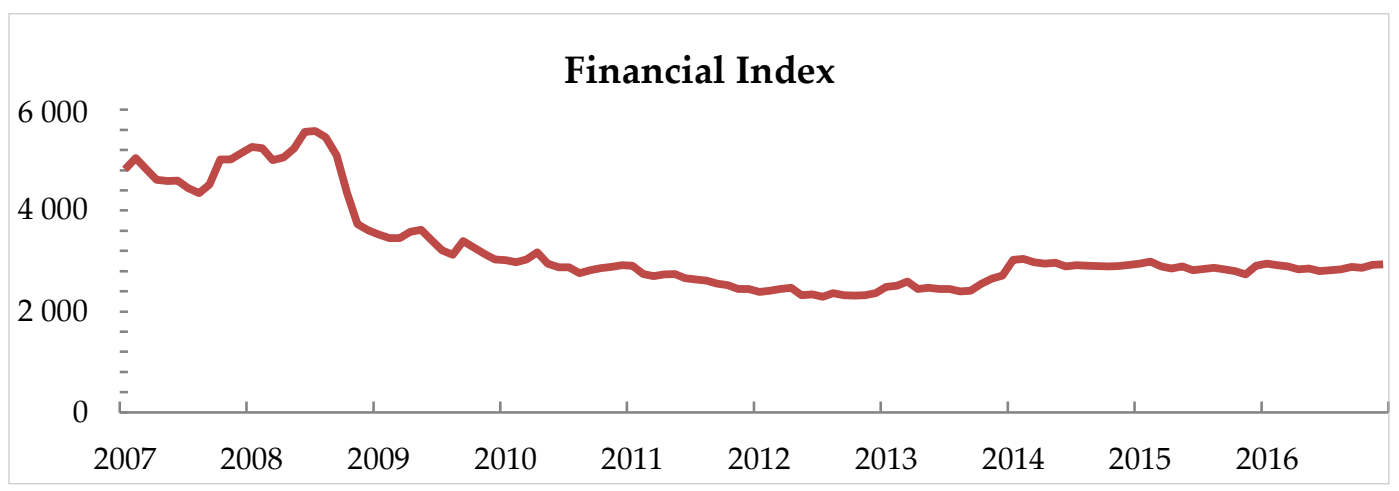

Figure 1. ASE financial index (2007-2016)

Source: Amman Stock Exchange.

The current study is reported as follows. Section 2 discusses the literature review, while data and methodology are provided in section 3. Section 4 presents the results and analysis. The conclusion and the policy implication, as well as the recommendations, are reported in section 5.

\section{LITERATURE REVIEW}

Studies such as Endress and Gear (2015); Hussain, Rafique, Khalil and Nawaz (2013); Bekhet and Matar (2013); Valera, Holmes and Hassan (2017); Adaramola (2012); Lin, Fang and Cheng (2010) focused largely on frontier markets and the stock price movements and recognised that stock prices can be influenced by the changes in different global and domestic economic indicators, as well as by movements in international stock markets. This is because domestic stock markets are correlated with the international stock markets (Peiró, 2016). This relationship is in line with the evidence provided by Fama (1981), who argued that different macroeconomic indicators (domestic and international) can influence stock prices, and the stock market can reflect the economic condition of a country.

Asmy et al. (2009) concluded that stock prices have a negative relationship with money supply in the long run, but a positive relationship in the short run. Hussain et al. (2013) conducted a study to examine the effect of macroeconomic variables on price index of the Karachi Stock Exchange (KSE-100). The results showed that interest rates have a significant negative impact on the price of the KSE-100 index but money supply showed a significantly positive impact on the KSE-100 index. Nishat, Shaneen and Hijazi (2004) concluded that there is a positive impact of industrial production on stock market index. Siliverstovs and Duong (2006) also demonstrated a positive influence of industrial production on stock market index in European economies. 
Using the GARCH (1,1) model, Boldanov et al. (2016) investigated the relationship between oil prices and stock volatility in three oil-importing countries (Japan, China, and the United States) and three oilexporting countries (Russia, Canada and Norway). They found that the change in oil prices have a positive impact on the stock prices in all the importing countries. Park and Ratti (2008) and Filis (2010) examined the impact of oil price movements on stock prices and found that almost all oil-importing countries' stock prices responded significantly to the oil price movements. Table 1 shows more findings and methods have been used in the previous studies regarding the relationship between the set macroeconomic indicators and stock prices.

Table 1

Summary of key findings for macroeconomic indicators and stock prices

\begin{tabular}{|l|l|l|l|l|}
\hline $\begin{array}{l}\text { Macroeconomic } \\
\text { Variable }\end{array}$ & Author & Country & Method & Findings \\
\hline IR & Mumo (2017) & Kenya & VECM model & Positive \\
\hline IR & Leong and Hui (2014) & Singapore & linear regression & Negative \\
\hline IR & $\begin{array}{l}\text { Vaz, Ariff and Brooks } \\
\text { (2008) }\end{array}$ & Australia & event study & No relationship \\
\hline M2 & Leong and Hui (2014) & Singapore & Linear regression & Positive \\
\hline M2 & Bekhet and Matar (2013) & Jordan & ARDL Approach & Negative \\
\hline M2 & $\begin{array}{l}\text { Maysami, Howe and Hamza } \\
\text { (2004) }\end{array}$ & Singapore & Johansen \& VECM & No relationship \\
\hline INFR & Ouma and Muriu (2014) & Kenya & OLS & Positive \\
\hline INFR & $\begin{array}{l}\text { Otieno, Ngugi and Muriu } \\
\text { (2018) }\end{array}$ & Kenya & FIECM \& ARFIMA & negative \\
\hline INFR & Dritsaki (2005) & Greece & Granger causality test & $\begin{array}{l}\text { Bidirectional } \\
\text { causality }\end{array}$ \\
\hline IPI & Filis (2010) & Greece & VECM \& VAR & Positive \\
\hline IPI & $\begin{array}{l}\text { Humpe and Macmillan } \\
\text { (2009) }\end{array}$ & US, Japan & Johansen \& VECM & No relationship \\
\hline IPI & Bekhet and Matar (2013) & Jordan & ARDL Approach & No relationship \\
\hline PPI & Sirucek (2012) & US & OLS & Positive \\
\hline PPI & $\begin{array}{l}\text { Fannery and } \\
\text { Protopapadakis (2002) }\end{array}$ & US & GARCH Model & Negative \\
\hline TB & $\begin{array}{l}\text { Antonakakis, Gupta and } \\
\text { Tiwari (2018) }\end{array}$ & US & GARCH model & Negative \\
\hline TB & Mehrara (2006) & Iran & Toda-Yamamoto & $\begin{array}{l}\text { Unidirectional } \\
\text { causality }\end{array}$ \\
\hline TB & Basabi and Jaydeep (2000) & India & Toda-Yamamoto & No relationship \\
\hline OIL & $\begin{array}{l}\text { Raza, Shahzad, Tiwari and } \\
\text { Shahbaz (2016) }\end{array}$ & $\begin{array}{l}\text { Emerging } \\
\text { markets }\end{array}$ & $\begin{array}{l}\text { NARDL Approach } \\
\text { Renewable } \\
\text { Energy Index }\end{array}$ & $\begin{array}{l}\text { positive } \\
\text { test }\end{array}$ \\
\hline OIL & Reboredo ct al. (2017) & $\begin{array}{l}\text { Causality in variance } \\
\text { model }\end{array}$ & $\begin{array}{l}\text { Bidirectional } \\
\text { causality } \\
\text { causality }\end{array}$ \\
\hline OIL & Jourional \\
\hline
\end{tabular}

Notes: IR (interest rate), M2 (Money supply), INFR (Inflation rate), IPI (Industrial production index), PPI (Producer price index), TB (Trade balance) and OIL (Crude oil prices). Source: Compiled by the authors. 
All in all, existing literature highlights the importance of investigating the relationship between the macroeconomic indicators and stock prices. Based on this premise, our study contributes to the literature by evaluating the relationship between domestic and international macroeconomic indicators and financial sector index in the context of a frontier market.

\section{METHODOLOGY}

The data for the current study were collected as monthly data for the period of January 2007 to December 2016. The study variables considered are the important macroeconomic indicators that play a significant role in the country. The data were collected from different sources. Interest rate (IR) and inflation rate (INFR) were collected from the Hashemite Kingdom of Jordan Department of Statistics; money supply (M2), industrial production index (IPI), producer price index (PPI), trade balance (TB) and crude oil price (OIL) were from the Thomson Reuters Datastream; the financial index price (FI) data were from the ASE. The long run relationship between the set macroeconomic indicators and financial index takes the following form:

$$
L F I_{t}=a_{0}+a_{1} I_{t}+a_{2} \mathrm{LM}_{t}+a_{3} \mathrm{INFR}_{t}+a_{4} \mathrm{LIPI}_{t}+a_{5} \mathrm{LPPI}_{t}+a_{6} \mathrm{~TB}_{t}+a_{7} \mathrm{LOIL}_{t}+\varepsilon_{t}
$$

Where, $a_{1} \ldots . a_{7}$ indicates the coefficient of the variables, $a_{0}$ is intercept term, $\varepsilon_{\mathrm{t}}$ represents the error term. We converted the variables into log form, except for IR, INFR and TB because these variables either include ratios such as IR or have negative values such as INFR and TB. Accordingly, LFI denotes to the financial index, while IR, LM2, INFR, LIPI, LPPI, TB, LOIL indicate the macroeconomic variables i.e. interest rate, a broad money supply, inflation rate, industrial production index, producer price index, trade balance and crude oil prices respectively. The current study examines the co-integration and the direction of the causality relationship between the domestic and international macroeconomic indicators and the financial sector index in Jordan. In doing so, the time series is to be tested to identify the stationary and integrated order. Therefore, Augmented Dickey Fuller (ADF) and Phillips-Perron (P-P) will be estimated to identify the stationary order of the time series. If some variables are stationary at level $\mathrm{I}(0)$ or/and at first difference I(1), then Autoregressive Distributed Lag (ARDL) approach will be useful because ARDL deals with the variables that are stationary at level $\mathrm{I}(0)$ or first difference $\mathrm{I}(1)$ or mixed. ARDL cannot be applied in case any variable was found to be stationary at second difference I(2). However, the ARDL approach has some advantages over the other existing methods. For example, the method is relatively simple to implement and is recommended for a small sample size (Ghatak \& Siddiki, 2001; Narayan, 2005; Pesaran, Shin \& Smith, 2001; Matar, 2016). Moreover, the variables are not restricted by a specific lag-length, which provides better results (Laurenceson \& Chai, 2003; Leong et al., 2018).

The current study also aims to analyse the causality relationship among the variables. The causality relationship can be estimated using different methods and models such as Vector Autoregressive (VAR) model and Vector Error Correction Model (VECM) model. The VECM is employed to identify the causality relationship in the short and long run once the results show there is co-integration between the variables (Insukindro, 2018). Otherwise, VAR model can be employed to examine the causality relationship. In fact, VECM has some advantages over the VAR model such as VECM provides the causality relationship in the long and short run (Bachmeier \& Griffin, 2006) while VAR provides the short run relationship. In our study, the ARDL bounds testing approach takes the following form: 


$$
\begin{aligned}
\Delta L F I_{t}=\alpha_{10}+ & \partial_{11} L F I_{t-1}+\partial_{12} I R_{t-1}+\partial_{13} L M 2_{t-1}+\partial_{14} I N F R_{t-1} \partial_{15} L I P I_{t-1} \\
& +\partial_{16} L P P I_{t-1}+\partial_{17} T B_{t-1}+\partial_{18} L O I L_{t-1}+\sum_{i=1}^{n} \theta_{11} \Delta L F I_{t-i} \\
& +\sum_{i=1}^{n} \theta_{12} \Delta I R_{t-i}+\sum_{i=1}^{n} \theta_{13} \Delta L M 2_{t-i}+\sum_{i=1}^{n} \theta_{14} \Delta I N F R_{t-i} \\
& +\sum_{i=1}^{n} \theta_{15} \Delta L I P I_{t-i}+\sum_{i=1}^{n} \theta_{16} \Delta L P P I_{t-i}+\sum_{i=1}^{n} \theta_{17} \Delta T B_{t-i} \\
& +\sum_{i=1}^{n} \theta_{18} \Delta L O I L_{t-i}+\varepsilon_{1 t}
\end{aligned}
$$

Where, $\Delta$ is the first difference, $\alpha_{10}$ denotes the constant term, $\partial_{11} \ldots \partial_{18}$ are the short run coefficients, while $\theta_{11} \ldots \theta_{18}$ relates to the long run coefficients, and finally $\varepsilon$ represents the error terms.

The null hypothesis $(\mathrm{H} 0)$ of the ARDL bound testing approach suggests that there is no co-integration and long run relationship among the variables, whereas the alternative hypothesis (H1) suggests that there is co-integration and a long run relationship among the variables. The acceptance or rejection of these hypotheses is subject to the following:

\begin{tabular}{cc}
\hline H0: No Co-integration relationship & H1: Co-integration relationship \\
\hline$\theta_{11}+\theta_{12}+\theta_{13}+\theta_{14}+\theta_{15}+\theta_{16}+\theta_{17}$ & $\theta_{11}+\theta_{12}+\theta_{13}+\theta_{14}+\theta_{15}+\theta_{16}+\theta_{17}$ \\
$+\theta_{18}=0$ & $+\theta_{18} \neq 0$ \\
\hline
\end{tabular}

Further, to accept or reject the null hypothesis above, the F-statistic of bound testing should be compared with the critical values, and one of the following results will be found:

If $\left\{F-\right.$ stat $\left.>I(1)_{\text {critical }}\right\}$ then the null hypothesis of no co-integration is rejected.

If $\left\{F-\right.$ stat $\left.<I(0)_{\text {critical }}\right\}$ then the null hypothesis of no co-integration is accepted.

If $\left\{I(0)_{\text {critical }}<F-\right.$ stat $\left.<I(1)_{\text {critical }}\right\}$, then the outcome isinconclusive.

However, as discussed earlier, to examine the direction of causality between the variables, VECM Granger causality will be applied once the results of the co-integration test showed that there is cointegration among the variables. The direction of causality relationship between two variables $\mathrm{X}$ and $\mathrm{Y}$ using the VECM model takes the following:

$$
\begin{aligned}
& \Delta X_{t}=\emptyset_{1}+\sum_{i=1}^{n} \alpha_{1} \Delta X_{t-1}+\sum_{i=1}^{n} \alpha_{2} \Delta Y_{t-1}+\partial_{1} E C T_{t-1}+\varepsilon_{t 1} \\
& \Delta Y_{t}=\emptyset_{2}+\sum_{i=1}^{n} \alpha_{3} \Delta Y_{t-1}+\sum_{i=1}^{n} \alpha_{4} \Delta Y_{t-1}+\partial_{2} E C T_{t-1}+\varepsilon_{t 2}
\end{aligned}
$$

Where, $\Delta$ is the first difference, ECT denotes to the error correction term, $\emptyset$ indicates the intercept terms, $\alpha_{1}$ to $\alpha_{4}$ are the short run coefficients, while $\partial_{1}$ and $\partial_{2}$ is the speed of adjustment for the explanatory variables.

\section{EMPIRICAL RESULTS AND DISCUSSION}

We begin with some descriptive statistics. Table 2 shows that financial index has a mean $(\mathrm{m})$ value of 3.49 , with a standard deviation (sd) of 0.10 . For the macroeconomic indicators, the statistics for interest rate 
$(\mathrm{m}=4.24, \mathrm{sd}=0.89)$, money supply $(\mathrm{m}=4.36, \mathrm{sd}=0.10)$, industrial production index $(\mathrm{m}=1.99, \mathrm{sd}=$ $0.02)$, producer price index $(\mathrm{m}=2.08$, $\mathrm{sd}=0.06)$, trade balance $(\mathrm{m}=-652.29$, sd $=169.25)$, crude oil price $(\mathrm{m}=1.87, \mathrm{sd}=0.14)$ and inflation rate $(\mathrm{m}=0.11, \mathrm{sd}=1.02)$ are as described. Except for INFR, data are within 3 standard deviations from their means. These denote the absence of extreme outliers for these particular indicators.

With respect to skewness, the variables LFI, IR, LM2 and LIPI had positive skewness values while INFR, LPPI, TB and LOIL had negative skewness. In addition, LFI, INFR and LPPI were leptokurtic, while others had kurtosis less than 3. Moreover, Jarque-Bera's P-values indicate that null hypothesis of normal distribution for LFI, IR, LM2, INFR and LOIL are rejected, but not for LIPI, LPPI and TB.

Table 2

Descriptive statistics of the indicators

\begin{tabular}{|c|c|c|c|c|c|c|c|c|}
\hline & LFI & IR & LM2 & INFR & LIPI & LPPI & TB & LOIL \\
\hline Mean & 3.49 & 4.24 & 4.36 & 0.11 & 1.99 & 2.08 & -652.29 & 1.87 \\
\hline Median & 3.46 & 4.12 & 4.38 & 0.10 & 1.99 & 2.08 & -663.40 & 1.91 \\
\hline Max & 3.74 & 5.74 & 4.51 & 6.00 & 2.03 & 2.23 & -260.65 & 2.14 \\
\hline Min & 3.35 & 2.95 & 4.14 & -3.40 & 1.93 & 1.93 & -1034.5 & 1.52 \\
\hline Std. Dev. & 0.10 & 0.89 & 0.10 & 1.02 & 0.02 & 0.06 & 169.25 & 0.14 \\
\hline Skewness & 1.07 & 0.18 & 0.37 & -1.36 & 0.02 & -0.42 & -0.02 & -0.65 \\
\hline Kurtosis & 3.02 & 1.56 & 2.05 & 11.74 & 2.98 & 3.20 & 2.24 & 2.38 \\
\hline J-Bera & 23.166 & 10.9 & 7.30 & 419.00 & 0.01 & 3.87 & 2.88 & 10.37 \\
\hline P-value & 0.00 & 0.00 & 0.02 & 0.00 & 0.99 & 0.14 & 0.23 & 0.00 \\
\hline
\end{tabular}

Source: Analyzed by the authors based on data from Hashemite Kingdom of Jordan Department of Statistics, Datastream and ASE.

Table 3 shows the result of the stationary test for examining the unit root in the time series by utilizing ADF and P-P tests. The results reveal that the financial index is non-stationary at the level $\mathrm{I}(0)$, but stationary at first difference $\mathrm{I}(1)$. Furthermore, for the macroeconomic indicators, the results demonstrate that LM2, INFR, LIPI, LPPI and TB are stationery at their level $(\mathrm{I}=0)$ while IR and LOIL are stationary at the first difference $(\mathrm{I}=1)$. Hence, the variables are found to be stationary either at level $\mathrm{I}(0)$, at first difference $\mathrm{I}(1)$, or both. These results provide evidence that the appropriate cointegration method for the current study is the Autoregressive Distributed Lag (ARDL). One of the most important advantages of the ARDL approach is that it deals with the variables that are stationary in the mixed order of integration.

As can be concluded from Table 4, the calculated F-statistics indicate that there is a cointegration relationship for all the models, except when the interest rate and global oil prices are dependent variables. The co-integration is inconclusive because the F-Statistic was found to be within the lower and upper critical bounds. However, for the main model (i.e. financial index which is a dependent variable) the results show that there is co-integration and significance at the $5 \%$ level running from the macroeconomic indicators to the financial index. Hence, the F-statistic was higher than the upper critical bound at $5 \%$ significance.

The diagnostics tests such as Heteroskedasticity-ARCH and Serial Correlation BreuschGodfrey demonstrate that the model is free from these problems. Heteroskedasticity-ARCH resulted in an F-statistic of 0.22 and a P-value of 0.80 , while Serial Correlation Breusch-Godfrey also resulted in an F-statistic of 0.252 and a P-value of 0.777 . These results demonstrate that we cannot reject the null hypothesis for both tests and that there is no heteroskedasticity or serial correlation in the model. 
$\mathrm{ADF}$ and P-P unit root tests

\begin{tabular}{|c|c|c|c|c|}
\hline \multirow{2}{*}{ Variables } & \multicolumn{2}{|c|}{ Level } & \multicolumn{2}{|c|}{ First Order Difference } \\
\hline & Constant & + Trend & Constant & + Trend \\
\hline \multicolumn{5}{|c|}{ Augmented Dickey Fuller Results } \\
\hline LFI & -1.83 & -1.34 & $-5.74 * * *$ & $-5.87 * * *$ \\
\hline IR & -2.13 & -2.51 & $-3.38^{* *}$ & $-3.35^{*}$ \\
\hline LM2 & $-3.24 * *$ & -1.74 & $-6.24 * * *$ & $-7.05^{* * *}$ \\
\hline INFR & $-3.73 * * *$ & $-4.69 * * *$ & $-9.86^{* * *}$ & $-9.82^{* * *}$ \\
\hline LIPI & $-4.23 * * *$ & $-4.19 * * *$ & $-7.05^{* * *}$ & $-7.04 * * *$ \\
\hline LPPI & $-3.43^{* *}$ & $-3.26^{*}$ & $-3.75^{* * *}$ & $-3.92 * * *$ \\
\hline TB & -1.78 & -2.19 & $-6.66^{* * *}$ & $-6.70 * * *$ \\
\hline LOIL & -2.35 & -2.76 & $-4.73 * * *$ & $-7.74 * * *$ \\
\hline \multicolumn{5}{|c|}{ Phillips-Perron Results } \\
\hline LFI & -1.82 & -1.18 & $-7.79 * * *$ & $-7.95 * * *$ \\
\hline IR & -1.07 & -1.56 & $-6.86 * * *$ & $-6.85^{* * *}$ \\
\hline LM2 & $-3.58 * *$ & -1.77 & $-9.54 * * *$ & $-10.31 * * *$ \\
\hline INFR & $-6.39 * * *$ & $-7.47 * * *$ & $-18.22^{* * *}$ & $-18.14 * * *$ \\
\hline LIPI & $-7.61 * * *$ & $-7.57 * * *$ & $-20.17 * * *$ & $-20.09 * * *$ \\
\hline LPPI & $-2.61 *$ & -2.30 & $-6.77 * * *$ & $-6.93^{* * *}$ \\
\hline TB & $-4.05^{* * *}$ & $-6.20 * * *$ & $-21.84 * * *$ & $-21.85^{* * *}$ \\
\hline LOIL & -2.13 & -2.54 & $-7.93 * * *$ & $-7.92^{* * *}$ \\
\hline
\end{tabular}

Note: ${ }^{*} \mathrm{p}<0.1 ;{ }^{* *} \mathrm{p}<0.05 ;{ }^{* * *} \mathrm{p}<0.01$. Source: Computed by the authors.

Table 4

Bounds Testing Model I: Financial Index

\begin{tabular}{|c|c|c|c|c|c|}
\hline Models & F-Stat & Decision & \multicolumn{3}{|c|}{ Critical bound } \\
\hline $\begin{array}{c}\text { (LFI, IR, LM2, INFR, LIPI, LPPI, TB, LOIL) } \\
(2,0,0,2,2,3,0,2)\end{array}$ & $4.18^{* *}$ & Co-integration & & & \\
\hline $\begin{array}{l}\text { (IR, LFI, LM2, INFR, LIPI, LPPI, TB, LOIL) } \\
(1,1,3,0,0,5,0,5)\end{array}$ & 2.82 & Inconclusive & Sig & $\mathrm{I}(0)$ & $\mathrm{I}(1)$ \\
\hline $\begin{array}{c}\text { (LM2, LFI, IR, INFR, LIPI, LPPI, TB, LOIL) } \\
(1,0,0,0,1,0,0,1)\end{array}$ & $3.39 *$ & Co-integration & $10 \%$ & 2.03 & 3.13 \\
\hline $\begin{array}{c}\text { (INFR, LFI, IR, LM2, LIPI, LPPI, TB, LOIL) } \\
(3,0,1,0,0,2,0,2)\end{array}$ & $12.64 * * *$ & Co-integration & $5 \%$ & 2.32 & 3.50 \\
\hline $\begin{array}{c}\text { (LIPI, LFI, IR, LM2, INFR, LPPI, TB, LOIL) } \\
(4,1,1,1,0,3,0,0)\end{array}$ & $5.58^{* * *}$ & Co-integration & $1 \%$ & 2.96 & 4.26 \\
\hline $\begin{array}{l}\text { (LPPI, LFI, IR, LM2, INFR, LIPI, TB, LOIL) } \\
(3,1,1,3,5,5,0,4)\end{array}$ & $4.95^{* * *}$ & Co-integration & & & \\
\hline $\begin{array}{l}\text { (TB, LFI, IR, LM2, INFR, LIPI, LPPI, LOIL) } \\
(1,0,1,1,0,1,0,1)\end{array}$ & $11.45^{* * *}$ & Co-integration & & & \\
\hline $\begin{array}{l}\text { (LOIL, LFI, IR, LM2, INFR, LIPI, LPPI, TB) } \\
(2,1,0,1,0,0,1,0)\end{array}$ & 2.78 & Inconclusive & & & \\
\hline
\end{tabular}

Note: used with an intercept and no trend. ${ }^{*} \mathrm{p}<0.1{ }^{* *} \mathrm{p}<0.05 ;{ }^{* *} \mathrm{p}<0.01$. Source: Analyzed by the authors.

For the long run relationship, it can be observed from Table 5 that interest rate positively and significantly affects the financial index in Jordan. As interest rate increases, it reduces the incentive to invest and encourages depositing of money in banks, thereby, augmenting the growth of financial sector. The magnitude of the coefficient attached to the variable interest rate is 0.082 , which shows that a $1 \%$ increase in rate of interest leads to an increase of approximately 0.082 points in LFI. These findings of the positive significant impact of the interest rate on the financial index are in line with the findings of Jawaid and Ul 
Haq (2012) who found co-integration and positive relation between interest rate and the banking sector in emerging country such as Pakistan. In addition, Mumo (2017) also found evidence that there is a positive relationship between the interest rate and stock prices in an emerging market such as the Nairobi Stock Exchange in Kenya.

The results show that the producer price index has a significant negative impact on the financial index. In fact, an increase in the producer price index means an increase in the costs of products that were made by the companies and this leads to the use of more money to finish the products. This increase in capital consumption finally reduces the liquidity and investments in the banks and the financial institutions. The magnitude of the coefficient attached to LPPI is -0.687 ; the value of the coefficient indicates that one unit increase in LPPI will decrease LFI by approximately 0.687 . Our finding of the negative impact of the LPPI on LFI is in line with Flannery and Protopapadakis (2002). Furthermore, we also modeled the effect of the global oil prices (LOIL) on the financial index of ASE. The impact of LOIL was found to negatively affect the LFI in the long run. The rise in the crude oil prices might lead to an increase in the costs of transportations and productions for the manufacturing firms, which results in the use of more money by these companies and finally leads to the reduction in the liquidity of the banks and financial institutions, which influence the financial sector. However, the coefficient value reveals that a one unit increase in LOIL leads to a decrease in LFI by approximately 0.254 .

Money supply was found to have an insignificant impact on the financial index. The results are consistent with Maysami et al. (2004). Moreover, the impact of inflation was negative but insignificant on the financial index. In fact, the results of the negative coefficient in the long run are consistent with the proxy effect hypothesis by Fama (1981). However, these results are in line with the findings of Mumo (2017) who concluded that inflation rate is negative but has an insignificant impact on the stock prices in Kenya. The effect of industrial production index remained positive but had insignificant impact on the financial index of ASE. Finally, the influence of trade balance on the financial index was found to be insignificant. These findings are in contrast to the findings of Antonakakis et al. (2018).

Table 5

ARDL Long-run relationship

\begin{tabular}{|l|c|c|c|c|c|}
\hline Variable & Coefficient & S. Error & t-statistic & P-value & Decision \\
\hline IR & 0.082 & 0.018 & 4.373 & $0.000^{* * *}$ & Significant \\
\hline LM2 & -0.056 & 0.276 & -0.204 & 0.838 & Insignificant \\
\hline INFR & -0.007 & 0.019 & -0.374 & 0.709 & Insignificant \\
\hline LIPI & 0.157 & 0.713 & 0.220 & 0.825 & Insignificant \\
\hline LPPI & -0.687 & 0.274 & -2.499 & $0.014^{* *}$ & Significant \\
\hline TB & -0.000 & 0.000 & -0.618 & 0.537 & Insignificant \\
\hline LOIL & -0.254 & 0.141 & -1.796 & $0.075^{*}$ & Significant \\
\hline C & 4.929 & 1.707 & 2.886 & $0.004^{* * *}$ & Significant \\
\hline R-squared & $(0.988)$ & \multicolumn{2}{|c|}{ D-W: $(2.02)$} & F-Stat & $(449.44)$ \\
\hline Adjusted R-squared & $(0.985)$ & \multicolumn{5}{|l}{ Prob. } & $(0.000)$ \\
\hline
\end{tabular}

Note: (1) used with an intercept and no trend, (2) D-W: denotes to Durbin-Watson Statistic, $(3) * \mathrm{p}<0.1 ;{ }^{* *} \mathrm{p}<0.05$; *** $\mathrm{p}<0.01$. Source: Computed by the authors.

Table 6 presents the results of the short run relationship and the error correction term (ECT). The estimation of the model fulfills all three criteria, i.e. it is significant, negative and less than one in magnitude, which shows that the tendency of convergence to long run equilibrium exists. In addition, the speed of adjustment towards long run equilibrium is $12.6 \%$ in one time interval. However, the results of the short run reveal that IR and LPPI are positively correlated with LFI, whereas LIPI and LOIL are negatively correlated with LFI. 
Table 6

ARDL Short-run Relationship

\begin{tabular}{|l|c|c|c|c|c|}
\hline Variable & Coefficient & Std. Error & t-Statistic & P-value & Decision \\
\hline$\Delta$ LFI(-1) & 0.192 & 0.089 & 2.141 & $0.034^{* *}$ & Significant \\
\hline$\Delta$ IR & 0.010 & 0.002 & 3.840 & $0.000^{* * *}$ & Significant \\
\hline$\Delta$ LM2 & -0.007 & 0.035 & -0.201 & 0.840 & Insignificant \\
\hline$\Delta$ INFR & -0.001 & 0.001 & -0.787 & 0.432 & Insignificant \\
\hline$\Delta$ INFR(-1) & -0.002 & 0.001 & -1.488 & 0.139 & Insignificant \\
\hline$\Delta$ LIPI & -0.209 & 0.069 & -3.041 & $0.003^{* * *}$ & Significant \\
\hline$\Delta$ LIPI(-1) & -0.125 & 0.063 & -1.986 & $0.049^{* *}$ & Significant \\
\hline$\Delta$ LPPI & 0.501 & 0.108 & 4.632 & $0.000^{* * *}$ & Significant \\
\hline$\Delta$ LPPI(-1) & 0.065 & 0.157 & 0.415 & 0.678 & Insignificant \\
\hline$\Delta$ LPPI(-2) & 0.159 & 0.113 & 1.402 & 0.163 & Insignificant \\
\hline$\Delta$ TB & 0.000 & 0.000 & -0.627 & 0.531 & Insignificant \\
\hline$\Delta$ LOIL & 0.049 & 0.033 & 1.494 & 0.138 & Insignificant \\
\hline$\Delta$ LOIL(-1) & -0.070 & 0.033 & -2.088 & $0.039^{* *}$ & Significant \\
\hline ECT(-1) & -0.126 & 0.029 & -4.352 & $0.000^{* * *}$ & Significant \\
\hline
\end{tabular}

Note: ${ }^{*} \mathrm{p}<0.1 ;{ }^{* *} \mathrm{p}<0.05 ;{ }^{* * *} \mathrm{p}<0.01$. Source: Analyzed by the authors.

Table 7 shows the results of the VECM. The causality results demonstrate that there is long run causality relationship running from the macroeconomic indicators (IR, LM2, INFR, LIPI, LPPI, TB and LOIL) to the financial index. The ECT in the model showed a negative coefficient (-0.18) and t-statistic (3.31 ) and a significant $\mathrm{p}$-value at $1 \%$. The results of the short run causality indicated that there is unidirectional causality running from LFI to IR and TB as well as from LPPI to LFI.

On the macroeconomic side, we found that the crude oil price affects the trade balance and producer price index in short run. In addition, money supply, inflation rate and industrial production significantly cause the interest rate in the short run. Further, inflation rate was found to highly and significantly affect the producer price index in short run.

Table 7

VECM Granger Causality

\begin{tabular}{|c|c|c|c|c|c|c|c|c|c|}
\hline & \multicolumn{8}{|c|}{ Short run Causality } & \multirow{2}{*}{ Long-run } \\
\hline & $\Delta \mathrm{LFI}$ & $\Delta \mathrm{IR}$ & $\Delta \mathrm{LM} 2$ & $\triangle \mathrm{INFR}$ & $\Delta \mathrm{LIPI}$ & $\triangle \mathrm{LPPI}$ & $\Delta \mathrm{TB}$ & $\Delta \mathrm{LOIL}$ & \\
\hline LFI & - & 0.56 & 0.86 & 1.17 & 0.30 & $2.50^{* *}$ & 0.64 & 1.25 & $-3.31 * * *$ \\
\hline IR & $3.08^{* *}$ & - & $2.24 * *$ & $2.66^{* *}$ & $2.56^{* *}$ & 0.76 & 1.31 & 1.52 & 0.71 \\
\hline LM2 & 1.51 & 0.25 & - & 0.67 & 1.25 & 1.45 & $1.88^{*}$ & 0.56 & 0.71 \\
\hline INFR & 1.51 & 1.54 & 0.26 & - & 0.22 & 1.59 & 0.51 & 0.35 & $-2.52^{* *}$ \\
\hline LIPI & 0.86 & 1.23 & 0.68 & 1.63 & - & 0.65 & $2.81 * *$ & 0.71 & 1.32 \\
\hline LPPI & 1.14 & 0.74 & 1.51 & $5.67 * * *$ & 0.23 & - & 0.34 & $7.23 * * *$ & 1.90 \\
\hline TB & $2.05^{* *}$ & 1.19 & 0.10 & 1.01 & $2.09 *$ & 0.44 & - & $1.90 *$ & 1.54 \\
\hline LOIL & 0.72 & 0.89 & 1.02 & 1.42 & 0.45 & 1.69 & 1.07 & - & 1.67 \\
\hline
\end{tabular}

Note: ${ }^{*} \mathrm{p}<0.1 ;{ }^{* *} \mathrm{p}<0.05 ;{ }^{* * *} \mathrm{p}<0.01$. Source: Computed by the authors.

Eventually, to check the estimated model's stability and creditability of the long run coefficient with the short run dynamics responses of financial index and its causes, we utilized cumulative sum (CUSUM) and cumulative sum of square (CUSUMQ), impulse response function (IRF), and variance decomposition (VDA) tests. The results of the two plots of cumulative sums of recursive residuals and cumulative sum of residuals squared gave the desired results, thus establishing the stability of the models in the long run. The 
graph lines did not cross any of the 5\% critical bounds lines. Pesaran and Pesaran (1997) tested the stability of the long run coefficients utilizing the same procedure.

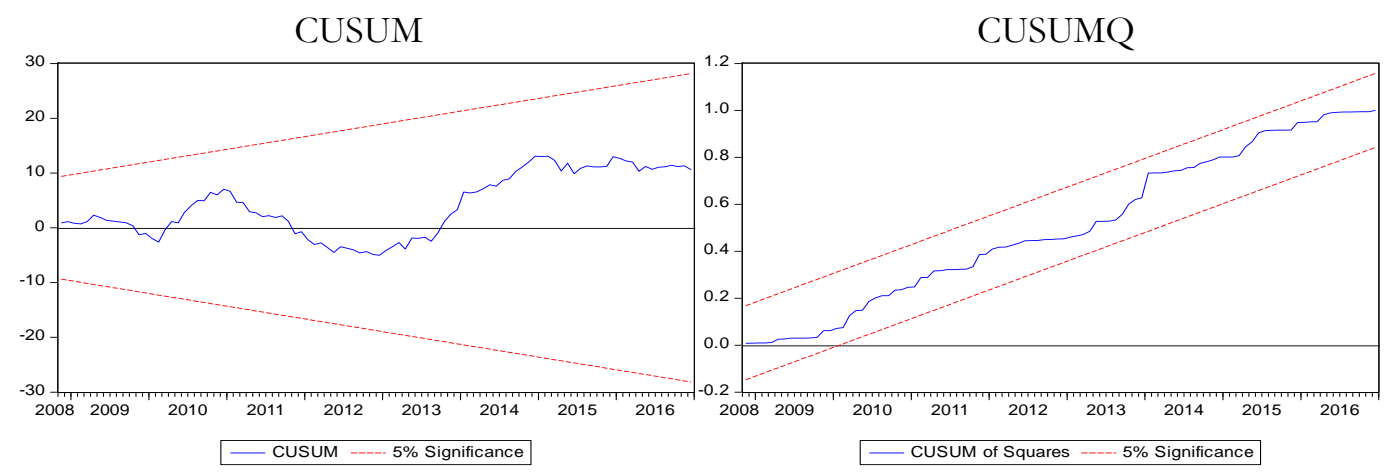

Figure 2. CUSUM and CUSUMQ for Financial Index Model (2007-2016)

Source: Analyzed by the authors.

Furthermore, we applied the IRF for 48 months to examine the short and long run response as well as to confirm the previous results. The results in Figure 3 indicate that IR registered a positive response during all periods. LPPI started with a positive response and within 3-4 months changed to be a negative response, while LOIL registered a weak negative response and reverted to insignificant positive response in the long run. Results are generally consistent with the findings described earlier. Moreover, INFR started with a positive response and later alternated between negative and positive. Money supply was found to have a negative response during all the period, while LIPI and TB showed some insignificant response. Therefore, the results of the IRF test confirmed the earlier results.
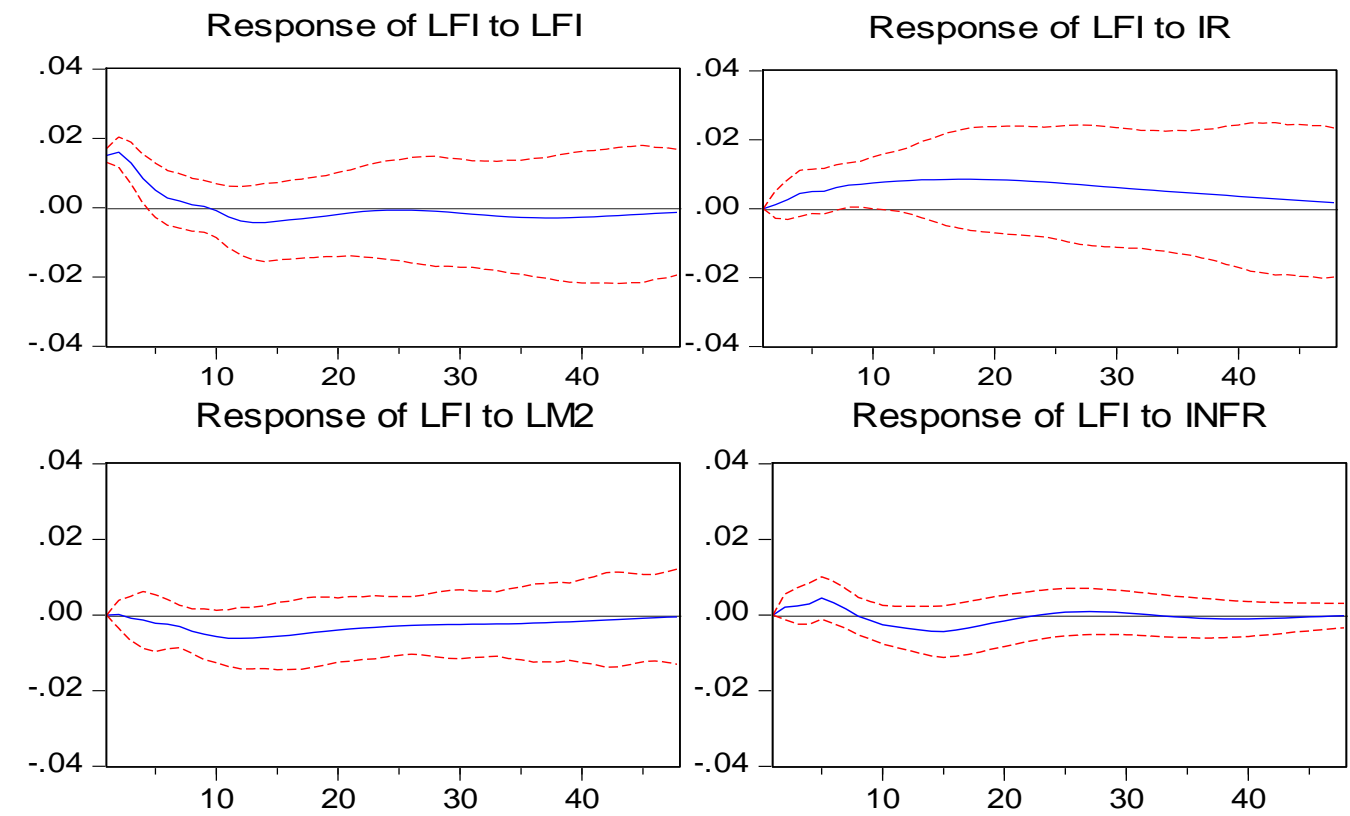

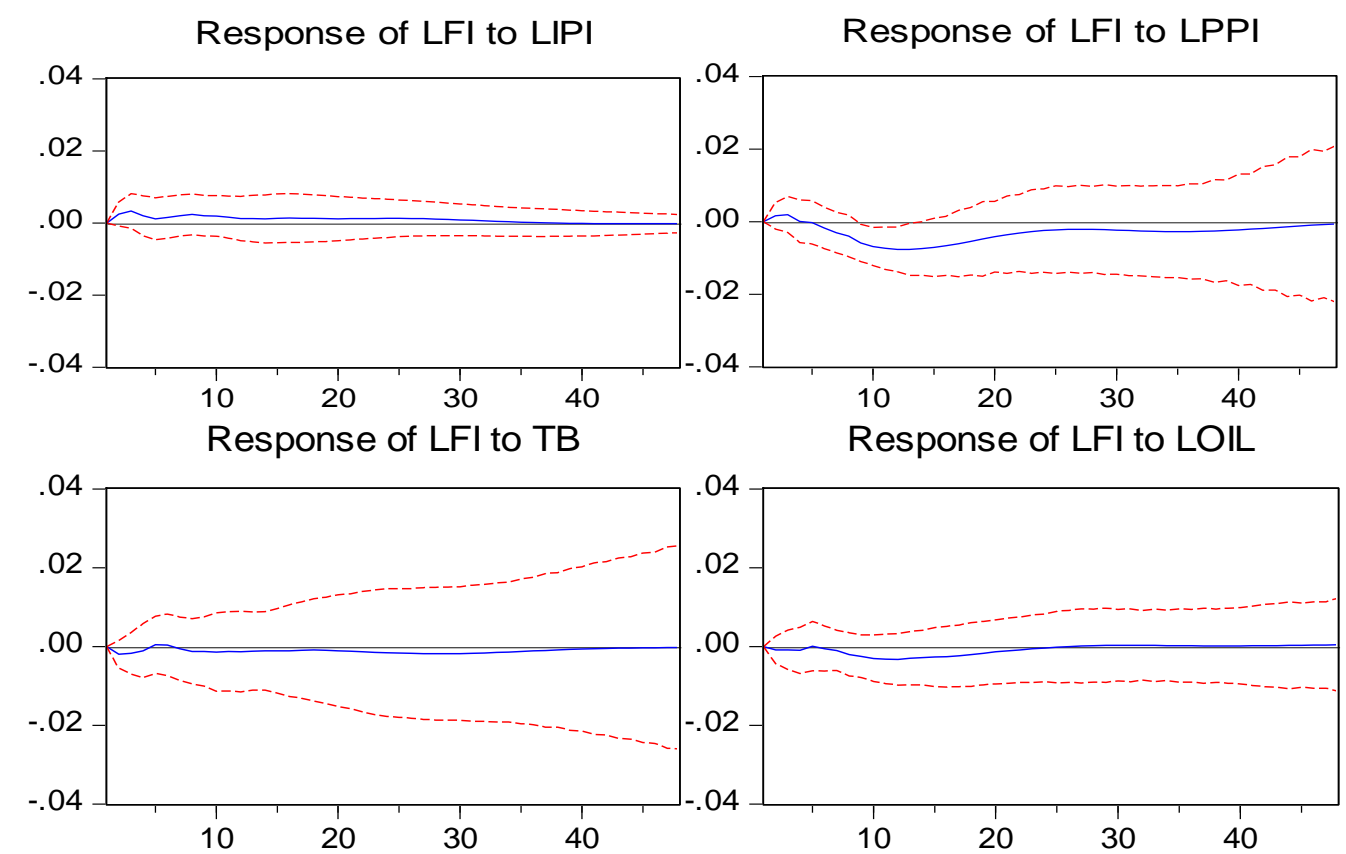

Figure 3. Impulse Response Function (IRF) for LFI model

Source: Analyzed by the authors.

The VDA test enables researchers to determine the most fluctuating sources of the endogenous variable for the duration of the study, while it also permits the estimation of the part of each endogenous variable as explained by the different shocks for different time frames (Lutkepohl, 1990). VDA was calculated for 48 months in Table 8 in order to establish the effects of included explanatory variables i.e. macroeconomic variables on the constant variable (financial index). In the first month, it was assumed that all the variance in the financial index was explained by its own innovations and all macroeconomic variables contributed zero.

Table 8

VDA of LFI

\begin{tabular}{|c|c|c|c|c|c|c|c|c|c|}
\hline Period & S.E. & LFI & IR & LM2 & INFR & LIPI & LPPI & TB & LOIL \\
\hline 1 & 0.015 & 100.000 & 0.000 & 0.000 & 0.000 & 0.000 & 0.000 & 0.000 & 0.000 \\
\hline 6 & 0.030 & 80.263 & 8.226 & 1.438 & 5.257 & 2.618 & 0.992 & 0.903 & 0.299 \\
\hline 12 & 0.042 & 44.128 & 22.074 & 9.985 & 4.688 & 2.595 & 13.003 & 0.993 & 2.530 \\
\hline 18 & 0.053 & 30.019 & 28.237 & 12.378 & 5.997 & 1.916 & 17.605 & 0.851 & 2.993 \\
\hline 24 & 0.058 & 25.229 & 34.758 & 12.545 & 5.196 & 1.829 & 16.753 & 1.002 & 2.685 \\
\hline 30 & 0.062 & 22.889 & 38.448 & 12.395 & 4.765 & 1.833 & 15.842 & 1.401 & 2.422 \\
\hline 36 & 0.064 & 22.185 & 39.642 & 12.317 & 4.468 & 1.732 & 15.770 & 1.622 & 2.259 \\
\hline 42 & 0.065 & 22.291 & 39.807 & 12.190 & 4.416 & 1.658 & 15.840 & 1.631 & 2.163 \\
\hline 48 & 0.066 & 22.401 & 39.909 & 12.104 & 4.386 & 1.640 & 15.789 & 1.623 & 2.144 \\
\hline
\end{tabular}

Note: S.E. stands for Standard Errors. Source: Computed by the authors.

It is evident in Table 8 that IR and LPPI are the factors that significantly contribute to explaining the variance in the financial index because IR and LPPI contributed approximately $55 \%$ to the financial index after 48 months. The strong contribution of interest rate over time indicates that IR would influence the financial index, especially in the long run. On the other hand, the trade balance and industrial production index registered the lowest values during the next 48 months, and this indicates that TB and LIP are insignificant in contributing to the financial index during such period. Moreover, INFR and oil price were 
found to contribute $4.39 \%$ and $2.14 \%$ respectively to the financial index after 48 months. These results confirm our earlier findings from the ARDL. Hence, the interest rate and producer price are the major factors that affect the financial index. Finally, the results show that financial index in Jordan can be influenced and explained by various factors.

\section{CONCLUSION}

This study examined the short run and the long run relationship as well as the causality relationship between domestic and global macroeconomic indicators and the financial index price in Amman Stock Exchange in Jordan. The domestic macroeconomic indicators included the deposit interest rate, broad money supply, inflation rate, industrial production index, producer price index and the trade balance, while the global indicator was represented by the crude oil price. We employed ARDL to estimate the cointegration and short-long run relationship. The approach is considered appropriate to explore the long and short run relationship. We found that deposit rate positively influences the financial index in the short and the long run. Moreover, the producer price index and the crude oil price were found to have a significant negative impact on the financial index in the long run. In addition, to identify the causality relationship and the direction of causality, we utilized the VECM approach. The advantage of VECM is that can be used to identify the short and long run causality especially if cointegration relationship exists between the variables. The results revealed that the set explanatory variables Granger cause the financial index in the long run. Moreover, the results of the short run causality demonstrated that there is unidirectional causality running from LFI to IR and TB, as well as from LPPI to LFI. In addition, we found that the inflation rate and the money supply cause the interest rate, but there is no evidence that interest rate causes the money supply or inflation rate. Furthermore, the global oil price was found to significantly cause the producer price index and trade balance in Jordan. Lastly, we applied impulse response and variance decomposition tests to examine which variables contribute more to the financial index in the next 48 months. The findings of IRF suggested that the financial index significantly responds to the shock of the explanatory variables. Moreover, interest rate and producer price index were the major factors that forecast the variance and contribute to the financial index in Jordan.

These results provide implications for the government, policy makers and investors. Our findings of the positive interest rate on the financial index might be due to the banking sector, which has the largest equity amount in ASE. The increase in the deposit interest rate leads to increased liquidity in the banks and then increases the amount of investments. Subsequently, this can increase profits and thus stock prices of these banks, which is reflected on the financial index. In other words, as interest rate increases, it reduces the incentive to invest and encourages depositing of money in banks, thereby, augmenting the growth of financial sector. Moreover, the variables of the price level such as the producer price index showed a significant and negatively impacts on the financial index. These results imply that the increase in the producer price index means an increase in the costs of products that were made by the companies and this leads to the use of more money to finish the products. This increase in capital consumption finally reduces the liquidity and investments in the banks and the financial institutions.

Our findings also imply that the global oil prices have a significant impact on the financial index in Jordan, which indicates that the ASE is correlated with the global markets and is sensitive to shocks of the global indicators. Thus, the recommendations for the government and policy makers is to monitor the global oil prices and forecast future changes in oil prices to avoid as many negative effects as possible before they actually occur and impact the financial sector. Monitoring and forecasting oil prices will be useful for the economy and other sectors in Jordan because the results also revealed that the oil price significantly cause the producer price index and trade balance. Investors who are concerned with the changes in money supply 
and inflation rate might be able to shift their investment into the financial sector given that it is not affected by these factors. Future research can extend our study by focusing on other sectors, such as the industrial and services sectors, which are also considered as important parts of the economy.

\section{ACKNOWLEDGEMENT}

Safwan Mohd Nor (corresponding author) is the RHB Islamic Endowed Scholar in Finance at the University of Malaysia Terengganu and Research Associate at the Victoria Institute of Strategic Economic Studies, Victoria University, Australia. The authors wish to thank RHB Islamic Bank Berhad for the financial support in publishing this paper (grant number: 53276). The authors also acknowledge the editors and reviewers whose comments have led to the improvement of this article. Usual disclaimers apply.

\section{REFERENCES}

Adaramola, A. O. (2012). Oil price shocks and stock market behaviour : The Nigerian experience. Journal of Economics, 3(1), 19-24. https://doi.org/10.1080/09765239.2012.11884948

Antonakakis, N., Gupta, R., \& Tiwari, A. K. (2018). Time-varying correlations between trade balance and stock prices in the United States over the period 1792 to 2013. Journal of Economics and Finance, 42(4), 795-806. https://doi.org/10.1007/s12197-018-9428-z

Asmy, M., Rohilina, W., Hassama, A., \& Fouad, M. (2009). Effects of macroeconomic variables on stock prices in Malaysia: An approach of error correction model. MPRA. Retrieved from: https://mpra.ub.unimuenchen.de/id/eprint/20970

Bachmeier, L. J., \& Griffin, J. M. (2006). Testing for market integration crude oil, coal, and natural gas. Energy Journal, 55-71. https://doi.org/10.5547/ISSN0195-6574-EJ-Vol27-No2-4

Bahmani-Oskooee, M., \& Ng, R. C. W. (2002). Long-run demand for money in Hong Kong: An application of the ARDL model. International Journal of Business and Economics, 1(2), 147.

Basabi, B., \& Jaydeep, M. (2000). Causal relationship between stock market and exchange rate, foreign exchange reserves and value of trade balance: A case study for India. Department of Economics, Jadavpur University, Kolkata700032, India.

Bekhet, H. A., \& Matar, A. (2013). Co-integration and causality analysis between stock market prices and their determinates in Jordan. Economic Modelling, 35, 508-514. https://doi.org/10.1016/i.econmod.2013.07.012

Boldanov, R., Degiannakis, S., \& Filis, G. (2016). Time-varying correlation between oil and stock market volatilities: Evidence from oil-importing and oil-exporting countries. International Review of Financial Analysis, 48, 209-220 https://doi.org/10.1016/j.irfa.2016.10.002

Borjigin, S., Yang, Y., Yang, X., \& Sun, L. (2018). Econometric testing on linear and nonlinear dynamic relation between stock prices and macroeconomy in China. Physica A: Statistical Mechanics and Its Applications, 493, $107-$ 115 https://doi.org/10.1016/i.physa.2017.10.033

Bouri, E. (2015). A broadened causality in variance approach to assess the risk dynamics between crude oil prices and the Jordanian stock market. Energy Policy, 85, 271-279. https://doi.org/10.1016/i.enpol.2015.06.001

Cutler, D. M., Poterba, J. M., \& Summers, L. H. (1989). International evidence on the predictability of stock returns. Unpublished manuscript, MIT.

Dickey, D. A., \& Fuller, W. A. (1979). Distribution of the estimators for autoregressive time series with a unit root. Journal of the American Statistical Association, 74(366a), 427-431. https://doi.org/10.2307/2286348

Driga, I., \& Dura, C. (2014). The financial sector and the role of banks in economic development. Financial Developement and Economic Growth, 598-603. Retrieved from: https://www.upet.ro/simpro/2014/proceedings/09\%20$\%$ 20ECONOMICS\%20AND \%20PUBLIC \%20ADMINISTRATION/9.2.pdf

Endress, T., \& Gear, T. (2015). Stock prices: Are intuitive or deliberate persons better forecasters?. Economics and Sociology, 8(4), 43-50. https://doi.org/10.14254/2071-789X.2015/8-4/3

Fama, E. (1981). Stock returns, real activity, inflation, and money. The American Economic Review, 71(4), 545-565. https://doi.org/10.2307/1806180 
Fama, E. F. (1990). Term-structure forecasts of interest rates, inflation and real returns. Journal of Monetary Economics, 25(1), 59-76. https://doi.org/10.1016/0304-3932(90)90045-6

Fama, E. F., \& French, K. R. (1988). Dividend yields and expected stock returns. Journal of Financial Economics, 22(1), 3-25. https://doi.org/10.1016/0304-405X(88)90020-7

Fama, E. F., \& French, K. R. (1989). Business conditions and expected returns on stocks and bonds. Journal of Financial Economics, 25(1), 23-49. https://doi.org/10.1016/0304-405X(89)90095-0

Fama, E. F., \& Schwert, G. W. (1977). Asset returns and inflation. Journal of Financial Economics, 5(2), 115-146. https://doi.org/10.1016/0304-405X(77)90014-9

Filis, G. (2010). Macro economy, stock market and oil prices: Do meaningful relationships exist among their cyclical fluctuations? Energy Economics, 32(4), 877-886. https://doi.org/10.1016/j.eneco.2010.03.010

Flannery, M. J., \& Protopapadakis, A. A. (2002). Macroeconomic factors do influence aggregate stock returns. Review of Financial Studies, 15(3), 751-782 https://doi.org/10.1093/rfs/15.3.751

Friedman, M., \& Schwartz, A. (1963). A monetary history of the United States, Princeton University Press.

Geske, R., \& Roll, R. (1983). The fiscal and monetary linkage between stock returns and inflation. The Journal of Finance, 38(1), 1-33. https://doi.org/10.1111/j.1540-6261.1983.tb03623.x

Ghatak, S., \& Siddiki, J. U. (2001). The use of the ARDL approach in estimating virtual exchange rates in India. Journal of Applied Statistics, 28(5), 573-583. https://doi.org/10.1080/02664760120047906

Humpe, A., \& Macmillan, P. (2009). Can macroeconomic variables explain long-term stock market movements? A comparison of the US and Japan. Applied Financial Economics, 19(2), 111-119. https://doi.org/10.1080/09603100701748956

Hussain, A., Rafique, M., Khalil, A., \& Nawaz, M. (2013). Macroeconomic determinants of stock price variations: an economic analysis of KSE-100 index. Pakistan Journal of Humanities and Social Sciences, 1(1), 28-46. https://doi.org/10.1089/hyb.2010.0019

Insukindro, I. (2018). The effect of twin shock on fiscal sustainability in Indonesia. Economics \& Sociology, 11(1), 75-84. https://doi.org/10.14254/2071-789X.2018/11-1/5

Jawaid, S. T., \& Haq, A. U. (2012). Effects of interest rate, exchange rate and their volatilities on stock prices : Evidence from banking industry of Pakistan. Theoretical and Applied Economics, 19(8).

Laurenceson, J., \& Chai, J. C. (2003). Financial reform and economic development in China. Edward Elgar Publishing.

Leong, C. C., \& Hui, T. K. (2014). Macroeconomic and non-macroeconomic variables linking to Singapore hotel stock returns. Advances in Hospitality and Leisure, (pp. 21-36). Emerald Group Publishing Limited. https://doi.org/10.1108/S1745-354220140000010000

Leong, C. M., Puah, C. H., \& Liew, V. K. S. (2018). The impact of divisia money on monetary model of exchange rate in Indonesia. Economics and Sociology, 11(2), 52-63. https://doi.org/10.14254/2071-789X.2018/11-2/4

Lin, C. C., Fang, C. R., \& Cheng, H. P. (2010). Relationships between oil price shocks and stock market: an empirical analysis from greater China. China Economic Journal, 3(3), 241-254. https://doi.org/10.1080/17538963.2010.562031

Lutkepohl, H. (1990). Asymptotic distributions of impulse response functions and forecast error variance decompositions of vector autoregressive models. The Review of Economics and Statistics, 72(1), 116. https://doi.org/10.2307/2109746

Maysami, R., Howe, L., Hamzah, M., (2004). Relationship between macroeconomic variables and stock market indices: co-integration evidence from stock exchange of Singapore's all-s sector indices. Jurnal Pengurusan, 24, 47-77.

Matar, A. (2016). A dynamic equilibrium relationship between foreign direct investment, electrical power consumption and gross domestic product in Jordan. Jordan Journal of Economic Sciences, 3(1), 13-29. https://doi.org/10.12816/0029854

Mehrara, M. (2006). The relationship between stock market and macroeconomic variables : A case study for Iran. Iranian Economic Review, 11(17), 138-148. 
Mensi, W. (2017). Global financial crisis and co-movements between oil prices and sector stock markets in Saudi Arabia: A VAR based wavelet. Borsa Istanbul Review. https://doi.org/10.1016/j.bir.2017.11.005

Mumo, M. P. (2017). Effects of macroeconomic volatility on stock prices in Kenya: A cointegration evidence from the Nairobi Securities Exchange (NSE). International Journal of Economics and Finance, 9(2), 1. https://doi.org/10.5539/ijef.v9n2p1

Narayan, P. K. (2005). The saving and investment nexus for China: Evidence from cointegration tests. Applied Economics, 37(17), 1979-1990. https://doi.org/10.1080/00036840500278103

Nishat, M., \& Shaheen, R. (2004). Macroeconomic factors and the Pakistani equity market. Pakistan Development Review, 43(4II), 619-637. https://doi.org/10.30541/v43i4iipp.619-637

Noor, M. H., \& Dutta, A. (2017). On the relationship between oil and equity markets: evidence from South Asia. International Journal of Managerial Finance, 13(3), 287-303. https://doi.org/10.1108/IJMF-04-2016-0064

Otieno, D. A., Ngugi, R. W., \& Muriu, P. W. (2018). The impact of inflation rate on stock market returns: evidence from Kenya. Journal of Economics and Finance, 1-18. https://doi.org/10.1007/s12197-018-9430-5

Ouma, W. N., \& Muriu, P. (2014). The impact of macroeconomic variables on stock market returns in Kenya. International Journal of Business and Commerce, 3(11), 1-31.

Oxman, J. (2012). Price inflation and stock returns. Economics Letters, 116(3), 385-388. https://doi.org/10.1016/j.econlet.2012.04.024

Park, J., \& Ratti, R. A. (2008). Oil price shocks and stock markets in the U.S. and 13 European countries. Energy Economics, 30(5), 2587-2608. https://doi.org/10.1016/j.eneco.2008.04.003

Peiró, A. (2016). Stock prices and macroeconomic factors: Some European evidence. International Review of Economics and Finance, 41, 287-294. https://doi.org/10.1016/i.iref.2015.08.004

Pesaran, M. H., \& Pesaran, B. (1997). Working with Microfit 4.0: interactive econometric analysis;[Windows version]. Oxford University Press.

Pesaran, M. H., Shin, Y., \& Smith, R. J. (2001). Bounds testing approaches to the analysis of level relationships. Journal of Applied Econometrics, 16(3), 289-326. https://doi.org/10.1002/jae.616

Raza, N., Shahzad, S. J. H., Tiwari, A. K., \& Shahbaz, M. (2016). Asymmetric impact of gold, oil prices and their volatilities on stock prices of emerging markets. Resources Policy, 49, $290-301$. https://doi.org/10.1016/i.resourpol.2016.06.011

Reboredo, J. C., Rivera-Castro, M. A., \& Ugolini, A. (2017). Wavelet-based test of co-movement and causality between oil and renewable energy stock prices. Energy Economics, 61, 241-252.

Roll, R. (1988). The international crash of October 1987. Financial Analysts Journal, 44(5), 19-35. https://doi.org/10.2469/faj.v44.n5.19

Schwert, G. W. (1990). Stock returns and real activity: A century of evidence. The Journal of Finance, 45(4), 1237-1257. https://doi.org/10.1111/j.1540-6261.1990.tb02434.x

Shahzad, S. J. H., Nor, S. M., Hammoudeh, S., \& Shahbaz, M. (2017). Directional and bidirectional causality between U.S. industry credit and stock markets and their determinants. International Review of Economics and Finance, 47, 46-61. https://doi.org/10.1016/i.iref.2016.10.005

Siliverstovs, B., \& Duong, M. H. (2006). On the role of stock market for real economic acitivity: Evidence for Europe. Berlin: DIW Berlin. German Institute for Economic Research, Discussion paper, 559. Retrieved from: http://opus.zbwkiel.de/volltexte/2007/6273/pdf/ dp599.pdf

Sirucek, M. (2012). Macroeconomic variables and stock market: US review. International Journal of Computer Science and Management Studies, 2(3), 1-9.

Valera, H. G. A., Holmes, M. J., \& Hassan, G. (2017). Stock market uncertainty and interest rate behaviour: A panel GARCH approach. Applied Economics https://doi.org/10.1080/13504851.2016.1223817

Vaz, J. J., Ariff, M., \& Brooks, R. D. (2008). The effect of interest rate changes on bank stock returns. Investment Management and Financial Innovations, 5(4), 221-236. 